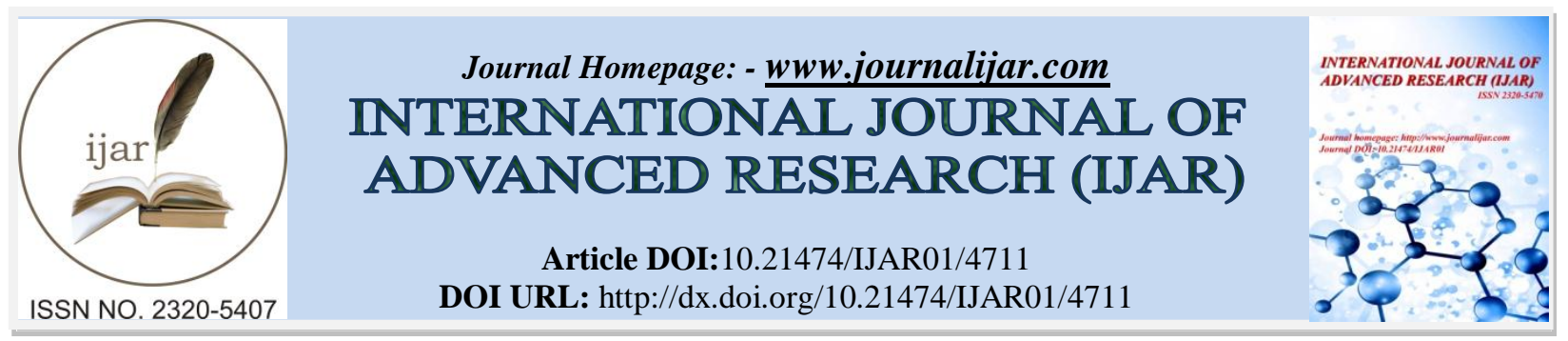

RESEARCH ARTICLE

\title{
COHESIVE DEVICES USED IN ENGLISH AND PILIPINO EXPOSITORY ESSAYS BY YOUNG ADULT FILIPINOS.
}

Noel B. Manarpiis.

Cavite State University - Tanza Campus, Philippines.

\section{Manuscript Info}

\section{Manuscript History}

Received: 3 May 2017

Final Accepted: 5 June 2017

Published: July 2017

Key words:-

Cohesive devices, L1 and L2 writing, L2

expository essays, L2 rhetoric

\section{Abstract}

The study used quantitative methodology and cross-sectional approach to determine cohesive devices used in English and Pilipino expository essays by Filipino college freshmen. These were correlated with raw scores they obtained. It revealed the cohesive devices they were supposed to use and those they frequently use or misuse. It found out why they ignored certain cohesive device. Instruments were used to elicit substantial results. Percentage, Pearson $r$ and one-factor ANOVA were used for analysis. The outputs were correlated using ttest for dependent or correlated means. Cohesives used were mostly definite articles, pronoun references and place and time markers, transitions, with support/evidence and cause and effect types. Cohesives were misused and abused only in the English essay. Cohesives used were those only known to them or what they only remembered. There was a very high positive correlation between the number of words used and the reference cohesion in the essays; a moderately small positive correlation between the total words used over the transitions; a moderately small positive correlation between the total words used to the raw score; and significant effect of reference cohesion, transition and raw scores. T-test showed a negative difference between students' English and Pilipino essays.

Copy Right, IJAR, 2017,. All rights reserved.

\section{Introduction:-}

Nishigaki et. al. (2007) assumed that producing a coherent and fluent piece of writing is an intimidating endeavour for most ESL/EFL students. They quoted Matsuhata (2000) who said that writing demands not only the integration of a wide variety of largely unfamiliar skills and strategies but success is often dependent on shared writing conventions between writers and readers, and familiarity with genre type and rhetorical conventions (Olshtain and Celce Murcia, 2003). Most people might perhaps think that compared with the Japanese, Chinese, Korean, Thai, or other Asians, the Filipino writers in English will not have the same problem as they have. But indeed, like their Asian counterparts, the Filipinos prioritize speaking their own language (L1) more than English which is just used academically or professionally. This is where problems arise when they commit mistakes in their English compositions. According to the views of contrastive analysis hypothesis (CAH) which was first developed by Fries (1945) and by Lado (1957), "mistakes made by L2 learners were caused by the native language." If these two CAH pioneers were to be the reference, then what is going on nowadays to the English composition outputs of the Filipinos may be blamed for their native language. 


\section{Pilipino as a means of communication in print and Media:-}

The Philippines is a multilingual and multicultural country composed of 110 languages and dialects (McFarland, 1994) all belonging to the language family of Austronesians (Malayo-Polynesian). The national language is Pilipino based on Tagalog which is widely spoken by more than 14 million people in Central Luzon, Southern Tagalog, and some parts of Mindanao. In other parts of the Philippines, Pilipino is widely used by another 25 million people or more as a second language where the locals speak their native or mother tongue in the comforts of their home but outside their abode, they have to negotiate, make trade, or do their business primarily and mainly using Tagalog. All over the country, Pilipino is used side by side with English in all aspects of Filipino's everyday circumstances. Nowadays though, the Filipinos have relied much in the use of Pilipino in literature, radio, press, and even in government and education. Before, no Philippine president, vice president, members of the congress and the cabinet officials could be heard speaking Tagalog in their official speeches and interviews. But in the 80s, when the late President Corazon C. Aquino came to power, she started speaking more Tagalog and most of the time resulted to code switching by speaking some English as well to local reporters in her official interviews in televisions and even in her speaking engagements around the country. From that time on, the succeeding presidents have continued the tradition. As an effect, local print and broadcast media started using Pilipino with English in commercials and soap operas. Presently, even imported soap operas from Korea and Japan and even old American and British movies are being dubbed or voiced in Pilipino. The everyday affair in the country is ruled by Filipino speakers especially in Philippine television being the most influential tool of communication for the ordinary and not-so ordinary Filipinos.

\section{Effects of presently using Pilipino more than English in print and Media:-}

Because of the present situation and the seeming reign of Pilipino over English in print and broadcast media, the impact of using the national language is lately evidently seen in Philippine schools as students use Pilipino more and more during recitations and classroom activities even in English classes. They argue that it is difficult for them to express themselves in English, thus they result to reasoning using Pilipino or code switch it with English. However, Thompson (2003) quoted Pascasio (1981) who argued that "To majority of the educated Filipinos, the function of English is for utilitarian purposes mainly in the domains of the school, business industry, and the judiciary courts. It is the language of international relations for the Philippines. It continues to be the language of worship. It is maintained as the language of wider communication, of trade, as well as entertainment, and as the language of instruction at all levels for Science, Technology, and Mathematics as provided in the bilingual policy." The year 2016 however offers a new perspective for the young adults and the much younger learners of this generation. Since the dominant language by far in the country is not anymore English but the national language, even Pilipino, there is much to investigate about how this present phenomenon has affected the skills of the young Filipino learners especially in speaking and writing.

The present research wanted to know what advantages or detriments Pilipino based on Tagalog has provided to the contemporary Filipino learners with the present situation as stipulated in this study. Utilizing their skill in writing through their knowledge in using cohesive devices, this research found out how much the young adult learners made use of cohesive devices in both English and Filipino expository writing.

\section{Analysis of the Problem:-}

This research looked into the use of cohesion of Filipino freshmen students in their English and Pilipino compositions. Specifically, the study answered the following questions:

1. What cohesive devices were used by the students in their English and Pilipino expository essays in terms of:

a. Reference cohesion that includes definite articles, pronouns and place and time markers

b. Transitions

2. What cohesive devices were supposed to be used by the Filipinos in their English and Pilipino expository essays but did not use at all?

3. What cohesive devices were misused or frequently used in their English and Pilipino expository essays?

4. Why did the students not use a certain cohesive device in their expository outputs when they could have done so?

5. What is the relationship of the amount of words used by the students in English and Pilipino essays on:

a. Reference cohesion used

b. Transition used

c. Raw score obtained by the students in their English and Pilipino composition

6. What is the significant effect of reference cohesion, transition used and the raw score obtained by the students in their expository essays? 
7. What is the difference between the expository essays written by the students in English to the one they wrote in Pilipino?

\section{Objectives of the Study:-}

The objectives of the present study are as follows:

1. Find out the cohesive devices used by the students in their English and Pilipino expository essays in terms of:

a. Reference cohesion that includes definite articles, pronouns and place and time markers

b. Transitions

2. Determine the cohesive devices the participants were supposed to use in their English and Pilipino expository essays but did not use at all

3. Discover what cohesive devices were misused or frequently used in their English and Pilipino expository essays

4. Find out what cohesive devices the students did not use in their expository outputs when they could have done so

5. Determine the relationship of the amount of words used by the students in English and Pilipino essays on:

d. Reference cohesion used

e. Transition used

f. Raw score obtained by the students in their English and Pilipino composition

6. Find out the significant effect of reference cohesion, transition used and the raw score obtained by the students in their expository essays

7. Discover the difference between the expository essay written by the students in English to the one they wrote in Pilipino

\section{Conceptual Framework:-}

The use of cohesion in expository writing in both English and Pilipino was investigated in the present study. The variables cohesive devices and expository essay were explored to come up with expected findings in cohesive devices being used by the students in English and Pilipino expository essays in terms of reference cohesion that includes definite articles, pronouns and place and time markers and transitions; cohesive devices that were supposed to be used by the students in English and Pilipino, yet, they did not use; and cohesive devices that were misused or abused in English and Pilipino essays.

The study also found out the amount of words used by the students in English and Pilipino essays on reference cohesion and transitions used; raw scores obtained by the students in their English and Pilipino composition; significant effect of reference cohesion, transition used and the raw score obtained by the students in their expository essays; and as a whole, the difference between English and Pilipino expository essays. The research paradigm is shown in Figure 1. 


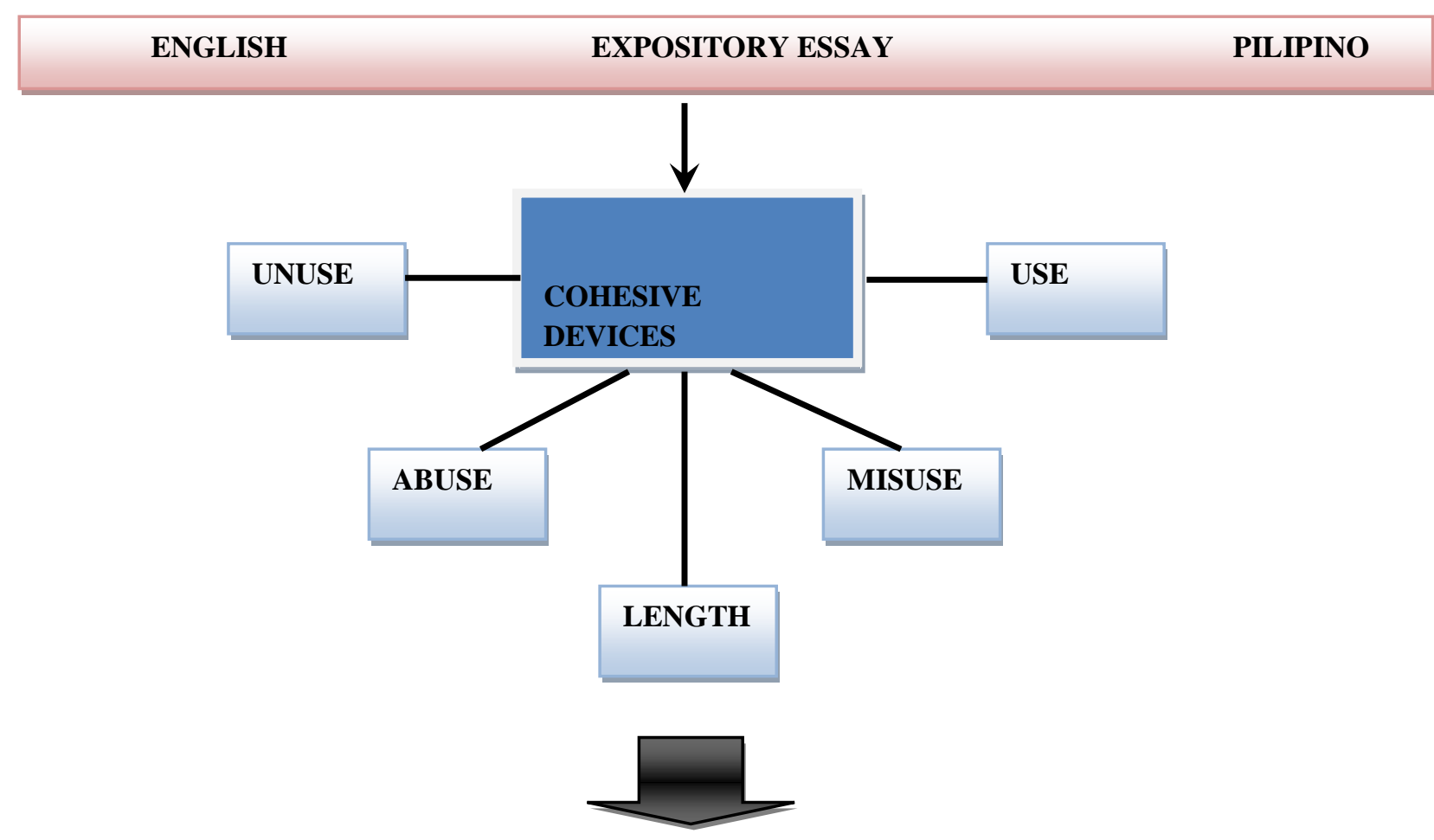

\section{EFFECTS AND DIFFERENCES}

\section{Methods:-}

Figure 1:- Paradigm of the study

\section{Research Design:-}

This study used the quantitative methodology and cross-sectional approach in research to determine the cohesive devices used in English and Filipino expository essays by college freshmen in the Philippines. The study found out various cohesive devices used, unused, misused or frequently used by these students in both languages. Also, the amount of words used per essay was observed. These variables were calculated using pertinent statistical analysis to come up with a significant effect of reference cohesion, transition used, and the raw score obtained by the students in their expository essays. Then, the difference between English and Pilipino expository essays was likewise observed.

\section{Participants:-}

The respondents of the study were the 35 Filipino college freshmen students from the Computer Science and Information Technology programs who at the time of the study were enrolled in the course English 2 - Writing in the Discipline.

Table 1 shows the distribution of the respondents:

Table 1:- Research participants

\begin{tabular}{|c|c|c|}
\hline Program & Male & Female \\
\hline Computer Science & 7 & 11 \\
\hline Information Technology & 8 & 9 \\
\hline TOTAL & $\mathbf{1 5}$ & $\mathbf{2 0}$ \\
\hline
\end{tabular}

\section{Research Instruments:-}

Writing prompt was used by the respondents as a springboard to lead them to writing their expository essay. A rubric was used as a scoring tool to evaluate the students' essays in English and Pilipino (see Table 2). Also, Halliday and Hasan's (1976) Taxonomy of Cohesive Device was used to refer to the cohesive devices that the respondents used in their output. Finally, the researcher took time out to interview each of the respondents by asking 
them how they processed their essays in English and Pilipino. They were asked why or why they did not use particular cohesive. The interview was conducted using Pilipino instead of English to give the respondents certain freedom to explain their work.

Table 2:- Criteria in grading the expository essay.

\begin{tabular}{|l|l|l|l|}
\hline Criteria & $\mathbf{1 = 2 0}$ & $\mathbf{2 = 1 2}$ & $\mathbf{3 = 8}$ \\
\hline Content (20\%) & Substantive & Some knowledge & With limited content \\
\hline Organization (20\% & Well organized & Ideas clearly supported & $\begin{array}{l}\text { Choppy with limited } \\
\text { support or non-fluent with } \\
\text { ideas disconnected }\end{array}$ \\
\hline Vocabulary (20\%) & $\begin{array}{l}\text { Sophisticated range of } \\
\text { vocabulary }\end{array}$ & $\begin{array}{l}\text { Limited range of } \\
\text { vocabulary }\end{array}$ & $\begin{array}{l}\text { Little knowledge of } \\
\text { vocabulary }\end{array}$ \\
\hline Language (20\%) & $\begin{array}{l}\text { Effective but simple } \\
\text { construction with main } \\
\text { problems in sentence } \\
\text { construction }\end{array}$ & $\begin{array}{l}\text { Showed major problems in } \\
\text { sentence construction }\end{array}$ \\
\hline Mechanics (20\%) & $\begin{array}{l}\text { Occasional errors of } \\
\text { spelling or punctuation } \\
\text { conventions }\end{array}$ & $\begin{array}{l}\text { No mastery of convention } \\
\text { with frequent errors of } \\
\text { spelling, punctuation and } \\
\text { paragraphing }\end{array}$ \\
\hline TOTAL SCORE: 100 & & & \\
\hline
\end{tabular}

\section{Data Gathering Procedure:-}

The respondents were given an extra-curricular activity by asking them to watch a popular Filipino stage play "El Filibusterismo," by the resident artists from Gantimpala Foundation. The stage play exposes the social cancer in the Philippines during the Spanish era. The students were instructed to jot down important notes that they could use in their essay. This play was their writing prompt.

After watching the play, the researcher gave them ample time to discuss the play in the English class. Then, the researcher asked the students to give a parallel scenario of Filipino sufferings in the present time.

A review of how to write an expository essay was presented in the class. At the end of the review, the student participants were asked to write an expository essay in English, requiring them to produce 300-350 word essay although if they could write more, they could do so. The following meeting, they were asked to write another essay of the same topic but this time in Pilipino. The same number of words was required.

After checking the papers, the researcher counted and tallied the cohesive devices and transitions used by the students using Halliday and Hasan's (1976) work as reference.

Then, the researcher interviewed each of the students to ask them why they did not use certain cohesions in their essays.

Later, the researcher correlated the different variables to come up with conclusions about their use, non-use, misuse or frequent use of cohesive devices.

\section{Data Analysis:-}

With percentage, Pearson $r$ was used to measure the correlations of the number of words used per essay over the number of reference cohesion and transition used and the raw score obtained by the students in the expository essay. One-way ANOVA was used to analyze the effect of relationships among reference cohesion, transitions and raw score of the students' essays. T-test for dependent or correlated means was used to interpret the difference between the expository essays written in English and Pilipino. 


\section{Results:-}

Result of essay output:-

Figure 2 reveals the result of the essays written by the students in English and Pilipino. The graph reveals that most of the students obtained low scores in their English essay (51/100 as highest and 12/100 being the lowest) while majority obtained higher scores in their Pilipino essay 95/100 as highest and 65/100 as the lowest score). Averaging the scores, the English essay made by the students obtained a mean of 29.54 only while their Pilipino essay obtained a mean of 79.83. This is an indication of the students' difficulty in dealing with the English language as opposed to their ease in producing ideas in their national language.

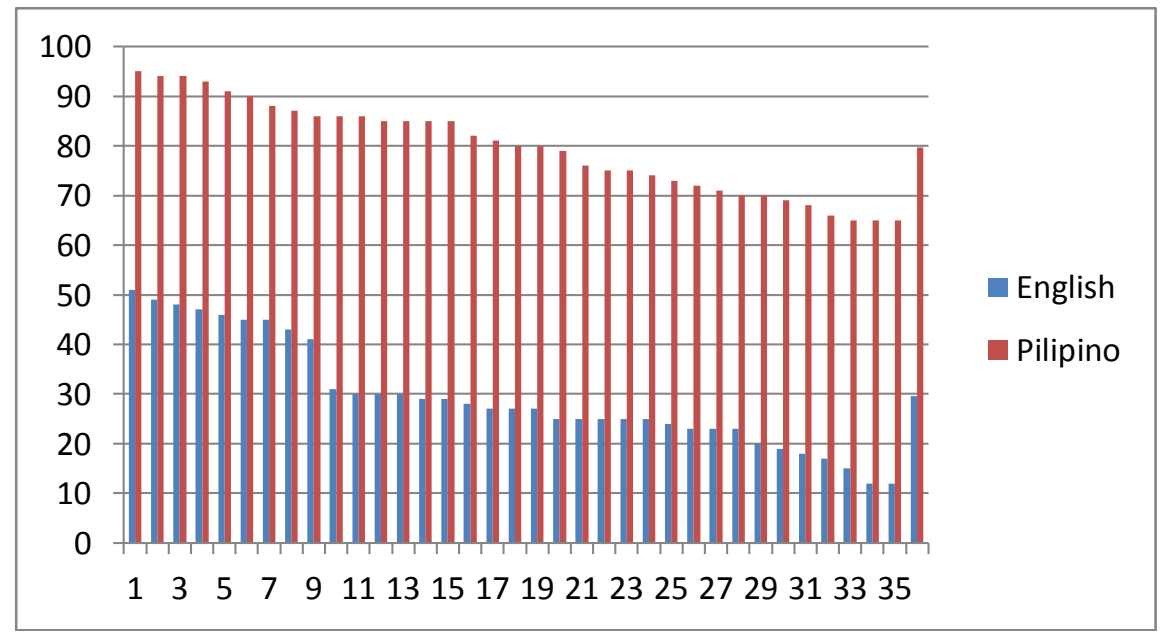

Figure 2:- Students' raw scores in English and Filipino

Amount of words produced:-

Figure 3 shows the amount of words produced by the students in their essays in English and Pilipino. The highest number of words produced in the English essay was 450 and the mean score for all the participants was 381.31. Meanwhile, the highest number of words produced in the Filipino essay was 475 and the mean score for all the participants was 421.42 .

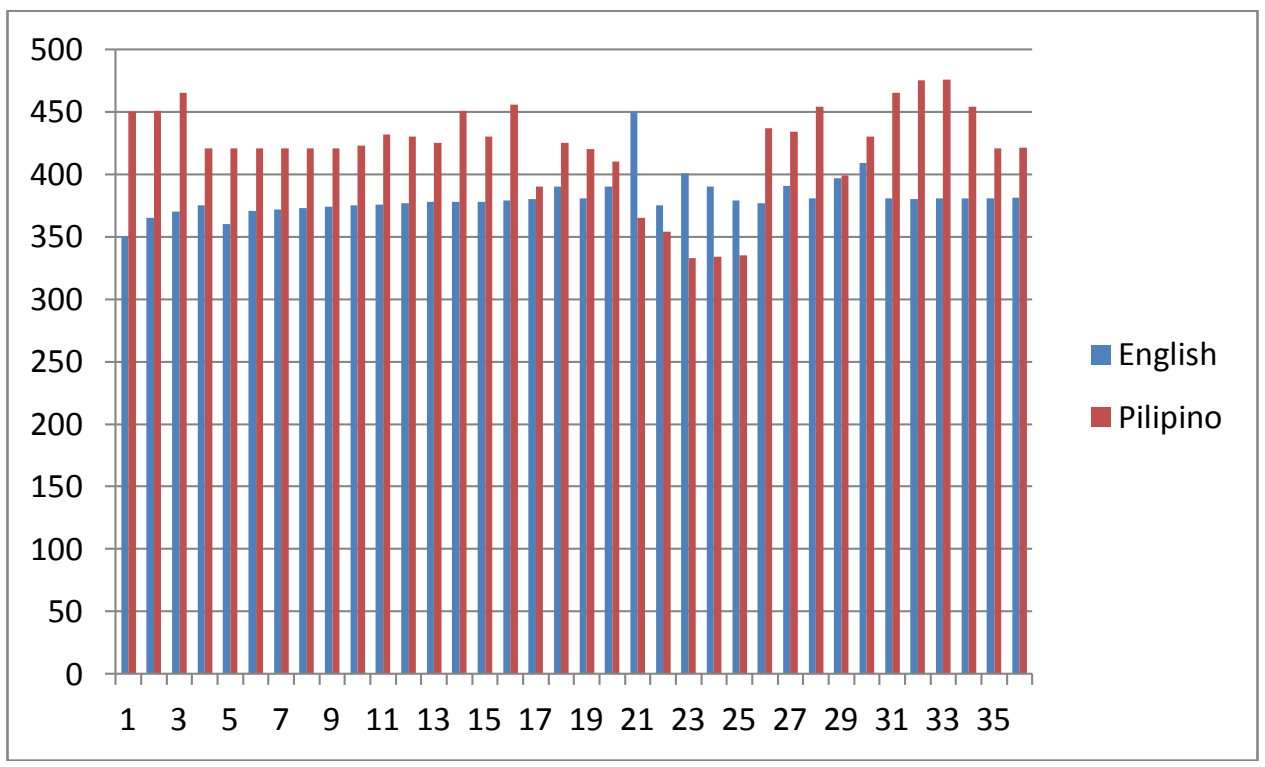

Figure 3:- Number of words used in the English and Pilipino essays 


\section{Reference cohesion used:-}

Figures 4 and 5 reveal the percentages of reference cohesion output of the respondents in both English and Pilipino. In English, the students produced 31 percent definite articles, 61 percent pronoun references and 8 percent place and time markers. In Pilipino, they produced 33 percent definite articles, 62 percent pronoun references and 5 percent place and time markers.

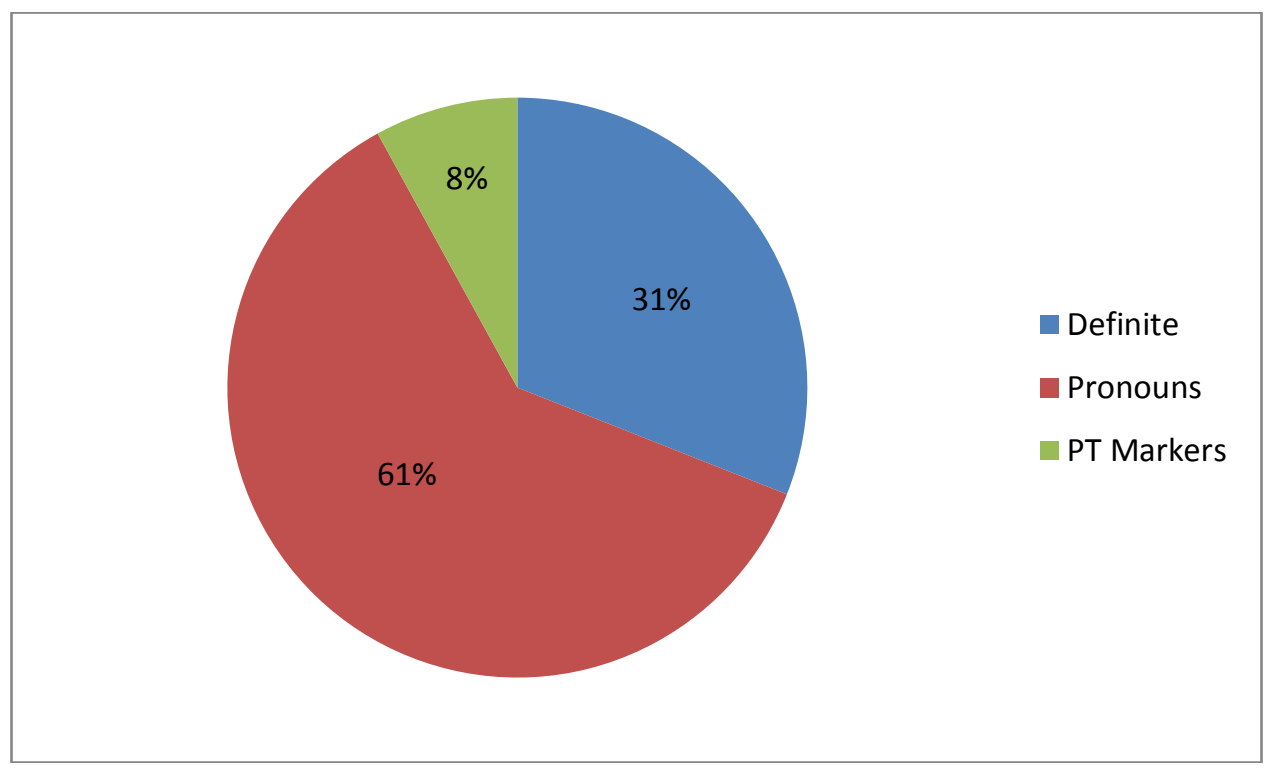

Figure 4:- Reference cohesion produced in English.

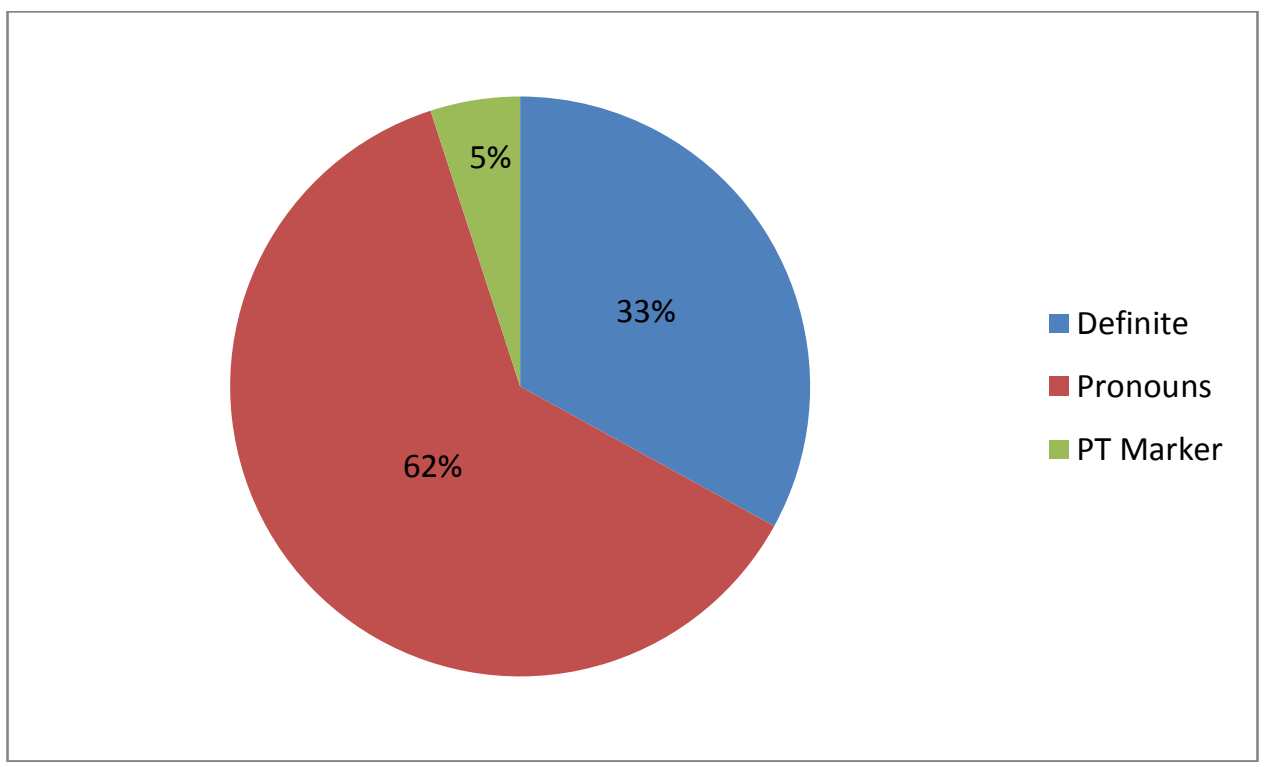

Figure 5:- Reference cohesion produced in Pilipino.

\section{Transitions used:-}

The transitions used in English by the students were as follows: average time/sequence/space used was 9 percent; average exception/contrast, 16 percent; average additional/evidence, 44 percent; average cause and effect 18 percent; average sequence/order, 1 percent; average emphasis, 3 percent; average summary conclusion, 1 percent; average similarity, less than 1 percent; average reformulation, less than one percent; average comparison/contrast, 1 percent; average inference, 2 percent; and average modifying phrases, 4 percent. 
In contrast, the Pilipino transitions used by the participants were 38 percent additional support used; 11 percent average time transition; 9 percent average cause and effect; 9 percent average emphasis; 12 percent average comparison and contrast; 9 percent average inference; other transitions, 12 percent. Figures 6 and 7 show the pie distribution of transitions used while Tables 3 and 4 show the details.

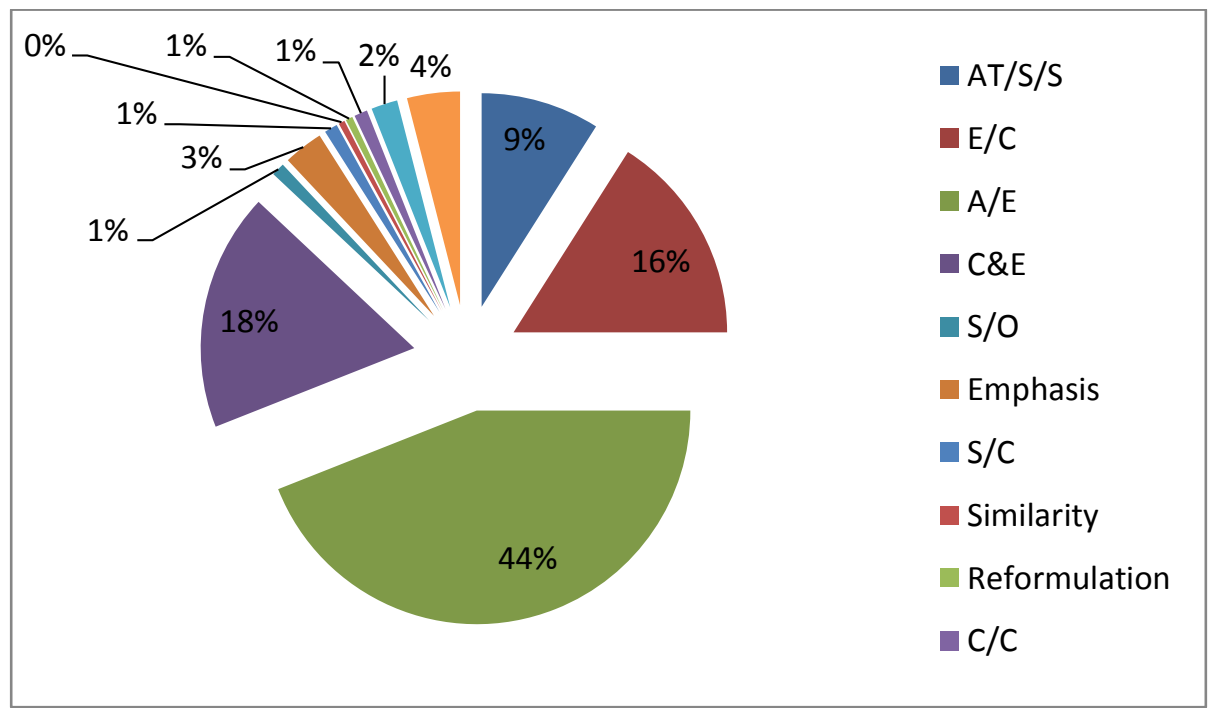

Figure 6:- Transition words used in English

Table 3:- Transitions used by the respondents in English expository essay.

\begin{tabular}{|c|c|}
\hline Kinds of Transitions & Transitions used \\
\hline Time/sequence/space & During \\
\hline Exception/contrast & But \\
\hline Additional support/evidence & And \\
\hline Cause and effect & At first \\
\hline Order/sequence & Even \\
\hline Emphasis & All these; As a result \\
\hline Summary/conclusion & As \\
\hline Similarity & That is \\
\hline Reformulation & Instead; In comparison \\
\hline
\end{tabular}

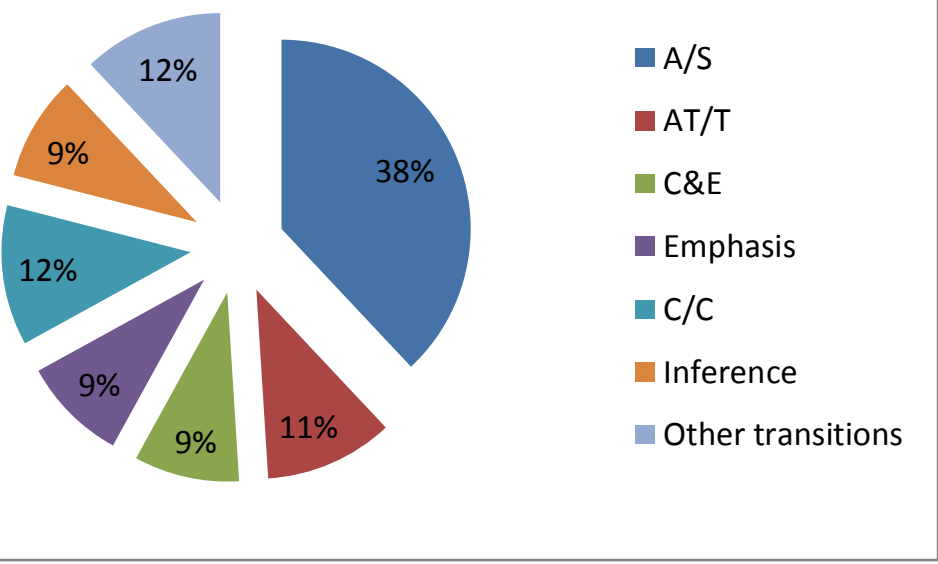

Figure 7:- Transition words used in Pilipino 
Table 4:- Transitions used by the respondents in Pilipino expository essay.

\begin{tabular}{|l|l|}
\hline Kinds of Transitions & Transitions used \\
\hline Time/sequence/space & Noong panahon; Sa kasalukuyan \\
\hline Exception/contrast & Maliban sa \\
\hline Additional support/evidence & At \\
\hline Cause and effect & Dahil, Bunga ng, Sapagkat, Upang \\
\hline Order/sequence & - \\
\hline Emphasis & Kahit na, Lalo na \\
\hline Summary/conclusion & Kaya \\
\hline Similarity & Gayundin \\
\hline Reformulation & - \\
\hline Comparison/contrast & Tulad ng dati \\
\hline Inference & Kung \\
\hline Example & Halimbawa \\
\hline Other transitions used & Kundi, Hanggang, Basta, Sana, Lamang, Bagkus \\
\hline
\end{tabular}

Cohesive devices not used:-

Table 5 reveals the cohesive devices that the students did not use in the English expository essay:

Table 5:- Cohesive devices the students were supposed to use in English essay

\begin{tabular}{|c|c|}
\hline Cohesive Types & Cohesive devices the students did not use \\
\hline Time/sequence/space & Meanwhile; over the next ... years \\
\hline Exception/contrast & Despite, in spite of; in contrast, on the contrary \\
\hline Additional support/evidence & What is more \\
\hline Cause and effect & Thus, hence \\
\hline Order/sequence & Second, third \\
\hline Emphasis & Indeed \\
\hline Summary/Conclusion & All the available transitions were not used \\
\hline Similarity & Just as, similarly, so too \\
\hline Reformulation & All except for that is \\
\hline
\end{tabular}

The cohesive devices the students did not use in Pilipino essay is found in Table 6:

Table 6:- Cohesive devices the students were supposed to use in Pilipino essay

\begin{tabular}{|c|c|}
\hline Cohesive Types & Cohesive devices the students did not use \\
\hline Sequence/order & Una, ikalawa, ikatlo \\
\hline Conclusion/Summary & All the devices were not used \\
\hline
\end{tabular}

Most frequently used cohesives:-

The most frequently used cohesive devices used in the students' English essay is found in Table 7.

Table 7:- Most frequently used cohesive devices used in English essay

During, and, because

Meanwhile, no cohesive devices were frequently used or misused in the Pilipino essays submitted by the respondents.

In a one-on one informal interview, 98 percent of the students said it did not occur to them to use some other cohesive devices other than the popular ones because they did not know how to use the devices correctly. When asked if they were acquainted with the other cohesive devices, they agreed. They also said that the cohesive devices that they did not use are not new to them. One factor why they did not use a certain cohesive device is due to the reason that they were writing under time pressure so they had to think of the more popular ones instead. In Pilipino essay, 94 percent of the students said that they could have used other devices but resulted to the more popular ones instead. The other six percent said they just used whatever they had in mind. 


\section{Statistical Results:-}

Using Pearson $\mathrm{r}$ correlation to measure the relationship of the number of words used in English and Pilipino expository essays to the reference cohesion, transitions and raw score used, it was found out that:

a. In terms of reference cohesion, $r=0.81$ means there was a very high positive correlation of the number of words used by the students in their expository essay to the reference cohesion that they used in their expository essay. In the Pilipino essay, $r=0.82$ which means a very high positive correlation of the number of words used by the students in their expository essay to the reference cohesion used in their Pilipino essay.

b. In terms of transition used in English essay, $r=0.47$ which showed a moderately small positive correlation of the number of words used by the students in their expository essay to the transitions used. In their Pilipino essay, $r=0.37$ which also showed a moderately small positive correlation between the number of words used by the students in their essay to the transitions they used.

c. In terms of the raw score obtained by each student in the English essay, $r=0.40$ meaning there was a moderately small positive correlation of the number of words used by the students in their essay to the raw score obtained in the essay. In Pilipino essay, $r=0.34$ showing a moderately small positive correlation between the number of words used by the students in their expository essay

According to findings for the significant effect of reference cohesion, transitions used and the raw score of the students in English essay, the F-ratio of $49.14>$ the tabular value of 3.086 at .05 level of significance using 2 degrees of freedom. This means there is a significant effect in the reference cohesion and transitions used and the raw score obtained by the students in their English essays. Looking at the Pilipino essay, the F-ratio of $296.75>$ the tabular value of 3.086 at .05 level of significance using 2 degrees of freedom. This means there is a significant effect in the reference cohesion and transitions used and the raw score obtained by the students in their Pilipino expository essay.

Overall, the hypothesis stating there is a significant effect of reference cohesion, transition used and the raw score obtained by the students in their expository essays is accepted.

Finally, using the t-test for dependent or correlated means, it was revealed that the computed t of $0.18<$ the tabular value of 2.032 at .05 level of significance using 2 degrees of freedom. Therefore, the English expository essay written by the students is negatively different to the Pilipino essay.

\section{Discussion:-}

Nishigaki et. al (2007) found out that the top five most frequently used transition signals among Japanese writers were "and, but, so, because, and when." Going back to the results found in this research, there is a similarity of frequent use between the Japanese and the Filipino learners. Perhaps, as Asians, the frequent use of the transition signals mentioned means that the Japanese and learners might have the same thought patterns as asserted by Kaplan (1966) when he studied about the Orientals.

About the amount of transitions used per essay, Basturkmen (2002) quoted Field and Yip's (1992) study about the Cantonese students who used at least 15 cohesive devices per essay. On the other hand, the present study collected 54 cohesive devices used by an average Filipino student. This is way ahead of their Asian counterparts mainly because of their exposure to the English language since kinder until college and even after college. English is a second language in the Philippines and an average Filipino speaks at least comprehensible English.

In the present study, in terms of cohesive devices, the problems found in the English essay of the participants were the same as the problem that occurs in their Pilipino output. For one, it was noticed in the output of the 35 students that all of them do not know how to use sequence order device. About 85 percent of the respondents both in English and Pilipino enumerated their argument with cohesive "two, three, next" but they never mentioned "first" to introduce their primary argument. Another discrepancy was the absence of the use of summary/conclusion which should be found at the end part of the essay. The students could have used "in conclusion, to sum up, with all these," but they failed to do so. The Japanese students says Nishigaki (2007) also did the same thing and placed the responsibility on the readers to understand their point. Back to the Filipino students, they terminate their discussion abruptly without using signals that will indicate that they are closing their discussion. So, even the Filipino writers have the same predicament as the Japanese. Again, there must be distinct similarities in their thought patterns being Orientals. 
With the help of Pearson $r$ to find out their similarities or dissimilarities, it was discovered that the students' essays resulted to the same findings of having high positive correlation of the number of words used in both English and Pilipino to the reference cohesion that they used. The same findings were observed in their use of transitions both in English and Pilipino. This shows the easiness on the part of the Filipinos in expressing their ideas in both languages because of their advantage in using English and Pilipino in school since kinder. They may have their struggles in processing their thoughts and eventually forgetting using cohesive devices, yet the Filipinos are L2 learners aside from being multilinguals. Even the ANOVA findings of significant effect reported the same result in both English and Pilipino which could be interpreted in the easiness of the Filipino learners in expressing their thoughts using both languages.

Surprisingly, the t-test for dependent or correlated means reported a negative correlation between English and Pilipino essays. It can be seen from the tables of findings that the students produced more cohesive devices in Pilipino. This is understandable because of their innate ability to speak their national language as compared to the difficulty that they experienced in using cohesive devices in English which is their second language. Using the criteria for checking the expository essay found in Table 2 of this study, results showed that the students obtained almost the same degree of difficulty in three of the five criteria - vocabulary, language, and mechanics - in both languages and not just in English. In the criteria organization and content, results showed they were either good in writing in English or Pilipino. Proficiency wise however, it can be concluded that the students' output in English is not in any way connected to their output in Pilipino.

\section{Conclusion:-}

The implication of the findings in the present research can be attributed to the high English skills of the Filipino students as opposed to the popular notion that English is fast deteriorating in the Philippines. In the same way, their output in Pilipino indicates a very strong foundation in their knowledge of their national language. This proves that the reason why Filipinos are adept in speaking English is that they have been well-trained in speaking and understanding Pilipino, their own language. For one, to be able to learn a new language, one must have a strong ground in his or her native language.

The students' output in both English and Pilipino had almost the same amount of words used. While the statistical result gave a moderately small positive correlation, yet, this result must alert the teachers in judging their students' output. Length does not matter but the substance must be given priority. The physical appearance of the essay including how long a student has written is not enough to say the student did not produce a substantial output.

The significant effect of reference cohesion, transitions used and the raw score of the students is a positive indication of a promising writing ability of a student. What emerges in this research best of all is that the students know how to produce cohesive and that they know how to use each of these cohesive devices. However, they must be given more training by their English and Pilipino teachers to improve their writing skills some more.

As for the negative outcome of comparison between English and Pilipino outputs, it can be argued that English being a Germanic language could not be compared to the Pilipino language being part of the Malayo-Polynesian group of Austronesian languages. They have their differences, structurally and culturally. In sentence construction alone, the English language has an S-V-O pattern as compared to the Pilipino pattern of V-S. The teachers have to put this in mind so that they will not compare their students' output in English and Pilipino.

In the end, it can be concluded that English is a formidable partner in raising the standards of education in the Philippines. However, educators must be reminded that the learners' second language can only be strong if their grasp of their native language or their national language is much stronger. Also, the Philippine educators or any other educators around the world must create an effective program for multilingual learners like the Filipinos so as to help them in appreciating the languages they know and learn at home and at school and even in the community. With a strong program to back up their skills in writing compositions, the learners will value their knowledge and become viable partners in nation-building. 


\section{References:-}

1. AbiSamra, N. (2003). An analysis of errors in Arabic speaker's English writings. American University of Beirut, $87 \mathrm{pp}$.

2. Basturkmen, H. (2002). Clause relations and macro patterns: cohesion, coherence, and the writing of advanced ESOL students. English Teaching Forum, pp. 50-56.

3. Benda, J. (1999). CCR 691 Methodological Community, Retrieved on October 21, 2016 at http://web.syr.edu/ jpbenda/methcomm.htm.

4. Connor, U. (2002). New directions in contrastive rhetoric. TESOL Quarterly vol. 36, no. 4, pp.493-507.

5. Field, Y. (1994). Cohesive conjunctions in the English writing of Cantonese speaking students from Hong Kong. ARAL, 17, 1, pp. 125-139.

6. Fries, Charles (1945). Teaching and Learning English as a Second Language. Ann Arbor: University of Michigan Press.

7. Halliday, M. A. K. and R. Hasan (1976). Cohesion in English. London: Longman.

8. Kaplan, Robert (1966). Cultural Thought Patterns in Intercultural Education, University of Southern California.

9. Lado, Robert (1957). Linguistics across Cultures, University of Michigan Press.

10. Liu, D. (2000). Writing cohesion: Using content lexical ties in ESOL. English Teaching Forum, 38, 1, pp. 2833.

11. McCarthy, M. and R. Carter (1994). Language as discourse. Harlow, U.K.: Longman.

12. Olshtein, E. and M. Celce-Murcia (2003). Discourse and Context in Language Teaching. Cambridge University Press.

13. Thompson, Roger M. (2003). Filipino English and Taglish: Language Switching from Multiple Perspectives. John Benjamins Publishing Co. Amsterdam: The Netherlands.

14. Tupas, T. R. (2006). Why do my students write the way they write: the problem of culture in teaching professional communication. Singapore Tertiary English Teachers Society (STETS) Vol 5.

15. VogtJ@missouri.edu (2006). Five-minute workshop in cohesion in writing. Curators of the University of Missouri DMCA and other copyright information. Retrieved on November 15, 2016 at http://cwp.missouri.edu/resources/five_minute_workshops_and_teaching resources/Five_Minute_Workshops/Cohesion_in_Writing.htm.

16. Wilcoxon, H. C. and K. Hayward (1991). Resolving problems with cohesion. New Horizons, 32, pp. 100-104.

17. Winter, E. (1977). A clause-relational approach to English texts: A study of some predictive lexical items in written discourse. Instructional Science, 6, 1, pp. 1-92. 